\title{
EFFECT OF CERTAIN WEATHER FACTORS ON POPULATION DENSITY OF Thrips tabaci LIND. ATTACKING ONION CROP
}

\author{
EL-SAPPAGH, I. A.
}

\author{
Plant Protection Research Institute- Agricultural Research Center- Dokki
}

(Manuscript received 10 December 2017)

\begin{abstract}
$(1$ hanges in the seasonal population of Thrips tabaci lind. attacking onion crop and the effect of certain weather factors were studied throughout (2015/2016 \& 2016/2017) onion growing seasons. T. tabaci appeared in few numbers by the $1^{\text {st }}$ week of January. Dynamics of the nymph and adult stages showed increasing steadily $3^{\text {th }}$ week of February until $1^{\text {st }}$ week of April. The values of correlation coefficient infer that infestation and degree days are positive correlated and non- significant. The weather factors as maximum temperatures and maximum \& minimum relative humidity didn't give significant correlation. On the contrary, the minimum temperature give significant correlation where $r=0.509$ with probability $p=0.031$ during first season. On the other hand, all weather factors were positively correlated with non significant except the minimum R.H. during second season. Considering, plant age as polynomial relation $(y=a+b 1 x$ $\left.+b 2 x^{2}+b 3 x^{3}\right)$ resulted in strong and significant correlation and regression.
\end{abstract}

\section{INTRODUCTION}

Onion (Allium cepa) is the most important plant infested by Thrips tabaci lind. (Afifi and Hayder (1990); Elkhayat et al. (1997) and Moawad (2003). The onion thrips is considered as one of the important insect pests attacking onion crops in Egypt.

Both nymphs and adults of Thrips tabaci attack the onion crop at all stages of its growth, resulting in reduction of yield and quality. Despite the heavy losses occurred as a result of damage by the onion thrips, very little efforts have been made to develop an integrated pest management strategy for the control of the pest in many African countries (Waiganjo et al. 2008).

The infestation by thrips appears early on onion and the outer leaves have silvery spots. It has been recorded to cause much damage and considerable loss in almost all onion growing fields. Nymphs and adults feed species feeding on leaves and in heavy infestation, they may cause stunted growth of plants, Hudak and Penzes (2004).

The present work was conducted to study the effect of certain weather factors on the population density of $T$. tabaci on onion represented as the ecological factors throughout two successive seasons. 


\section{MATERIALS AND METHODS}

The present work was initiated to investigate the efficiency of weather factors i. e. temperature and relative humidity degrees on population density of $T$. tabaci.

The studies were carried out under natural field conditions in Qaliubiya Governorate during the two seasons of onion (2015/2016 and 2016/2017). The normal agricultural practices were done without any pesticides application.

Onion plants were cultivated about in second week of December in the two seasons. The first inspection started on the first week of January and about 18 inspections were taken weekly around the onion-growing season. Counts were made at seven day intervals.

Plants examination started two weeks after transplanting and continued until harvesting. The samples were inspected during the period from January 2016 to May 2017. Weekly samples of ten plants were chosen at random from each plot. Nymphs and adults of $T$. tabaci are counted directly on a white paper in the field.

Three periods of onion plant ages after planting had been taken into consideration to evaluate their effect on the infestation rate of thrips.

Weekly means of maximum and minimum temperature $\left({ }^{\circ} \mathrm{C}\right)$ and maximum \&minimum relative humidity (R.H\%) were obtained from the Central Laboratory for Agriculture Climate and then recorded to correlate with mean numbers of thrips in the two studied seasons.

The explained variance $\%$ and simple correlation and regression between mean number of $T$. tabaci and the previous weather factors were estimated by using SAS program computer (SAS Institute, 2008).

\section{RESULTS AND DISCUSSION}

\section{Population density of $T$. tabaci on onion plants: First season (2015/2016):}

Data in Table (1) and Fig. (1) indicated that, in the first season, the infestation of the insect began to appear with 3.3 individuals / plant at $3^{\text {rd }}$ of January and recorded the first peak as 20.9 individuals / plant at $31^{\text {st }}$ of January. The population decreased in the followed inspection to reach 15.4 individuals / plant at $7^{\text {th }}$ of February then increased to reach the second peak 22.7 individuals / plant at $14^{\text {th }}$ February then decreased to 14.2 individuals / plant and increased again in the five successive inspections to reach the third peak ( 66.5 individuals / plant) at $28^{\text {th }}$ of March. Afterwards, the population declined to 13.2 individuals / plant at the harvest time. The sudden drop in the population may be due to maturation of the crop, leaf hardening and migration of thrips to other crops (Farman et al. 2010). 


\section{Second season (2016/2017):}

Data in Table (1) and Fig. (1) indicated that, in 2016/2017 season, the first number of $T$. tabaci recorded at $2^{\text {nd }}$ January with 4.5 individuals / plant at $2^{\text {nd }}$ of January then increased to reach the first peak with 19.6 individuals / plant at $30^{\text {th }}$ of January and then downs and ups to reach the second peak 33.3 individuals / plant at $13^{\text {th }}$ of February. The third peak of population represented with 65.8 individuals / plant was recorded at $27^{\text {th }}$ of March. The last five inspections recorded decreasing in thrips numbers to reach 8.2 at $1^{\text {st }}$ of May.

The maximum thrips population ( 66.5 thrips /plant) was recorded during $28^{\text {th }}$ March when the weekly mean of day temperature and weekly mean of day R.H. were 26.0 and 71.71 during this period, respectively during first season. On the other hand, it was 65.8 thrips/ plant recorded during $27^{\text {th }}$ March when the weekly mean of day temperature and weekly mean of day R. H. were 24.43 and 83.0 , respectively during second season.

\section{Effect of certain weather factors on the population density of T. tabaci:}

Regard to sensitivity of thrips during first season to the physical factors, the data in Table (2) revealed that both maximum \& minimum temperature and maximum relative humidity were positively correlated with thrips numbers $r=0.467,0.509$ and 0.457 , respectively while, minimum R.H. had negative correlation where $r$ value = 0.123. On the other hand, the weather factors such as maximum temperature and maximum relative humidity had positive and non-significant while the minimum temperature had positive correlated with significant effect. On the contrary, the minimum relative humidity had negative correlated and non- significant effect on the population density of onion thrips ( $r=-0.123$ with probability 0.627 ). 
Table 1. Effect of temperature and relative humidity on the population density of onion thrips in Qaliubiya Governorate during (2016 and 2017) seasons.

\begin{tabular}{|c|c|c|c|c|c|c|c|c|}
\hline $\begin{array}{c}\text { Date of } \\
\text { inspection }\end{array}$ & $\begin{array}{c}\text { Mean No. of } \\
\text { Thrips tabaci } \\
\text { /one plant }\end{array}$ & $\begin{array}{c}\text { Weekly } \\
\text { mean } \\
\text { of day } \\
\text { Temp. }\end{array}$ & $\begin{array}{c}\text { Weekly } \\
\text { mean } \\
\text { of day } \\
\text { R. H. }\end{array}$ & $\begin{array}{c}\text { Date of } \\
\text { inspection }\end{array}$ & $\begin{array}{c}\text { Mean No. of } \\
\text { Thrips tabaci } \\
\text { /one plant }\end{array}$ & $\begin{array}{c}\text { Weekly } \\
\text { mean } \\
\text { of day } \\
\text { Temp. }\end{array}$ & $\begin{array}{c}\text { Weekly } \\
\text { mean } \\
\text { of day } \\
\text { R. H. }\end{array}$ \\
\hline \multicolumn{2}{|c|}{ 2015/2016 } & \multicolumn{4}{|c|}{ 2016/2017 } \\
\hline 03-Jan & 3.3 & 18.57 & 61.14 & 02-Jan & 4.5 & 16.86 & 67.14 \\
\hline 10-Jan & 4.6 & 14.29 & 68.14 & 09-Jan & 6.8 & 17.70 & 72.43 \\
\hline 17-Jan & 6.5 & 16.00 & 79.57 & 16-Jan & 8.5 & 18.43 & 77.43 \\
\hline 24-Jan & 7.7 & 21.43 & 65.29 & 23-Jan & 10.8 & 19.14 & 85.57 \\
\hline 31-Jan & 20.9 & 19.57 & 83.29 & 30-Jan & 19.6 & 18.29 & 72.00 \\
\hline 7-Fab & 15.4 & 22.57 & 59.29 & 6-Fab & 14.2 & 18.43 & 85.14 \\
\hline 14-Fab & 22.7 & 17.57 & 70.43 & 13-Fab & 33.3 & 21.43 & 83.29 \\
\hline 21-Fab & 14.2 & 15.71 & 88.43 & 20-Fab & 27.5 & 16.43 & 84.29 \\
\hline 28-Fab & 34.9 & 20.71 & 79.57 & 27-Fab & 27.5 & 22.00 & 88.71 \\
\hline 07-Mar & 44.4 & 21.86 & 84.57 & 06-Mar & 28.0 & 23.29 & 85.57 \\
\hline 14-Mar & 51.0 & 24.14 & 88.86 & 13-Mar & 39.1 & 23.57 & 71.86 \\
\hline 21-Mar & 55.1 & 21.00 & 85.71 & 20-Mar & 65.0 & 22.00 & 74.29 \\
\hline 28-Mar & 66.5 & 26.00 & 71.71 & 27-Mar & 65.8 & 24.43 & 83.00 \\
\hline 04-Apr & 47.9 & 26.00 & 80.86 & 03-Apr & 43.6 & 26.43 & 80.71 \\
\hline 11-Apr & 43.0 & 26.57 & 74.00 & 10-Apr & 43.4 & 26.86 & 82.86 \\
\hline 18-Apr & 29.1 & 21.43 & 84.14 & 17-Apr & 27.5 & 26.57 & 83.71 \\
\hline 25-Apr & 22.0 & 26.57 & 66.43 & 24-Apr & 12.2 & 30.71 & 66.29 \\
\hline 02-May & 13.2 & 30.86 & 75.71 & 01-May & 8.2 & 28.86 & 75.71 \\
\hline Mean & 27.9 & 21.7 & 76.0 & Mean & 27.0 & 22.3 & 79.2 \\
\hline
\end{tabular}

Concerning the effect of weather factors on the population density of onion thrips during the second season, data indicated that there are positive correlated and non-significant effects on the population density of thrips where $r$ values were 0.285 , 0.376 and 0.212 with probability values $0.251,0.124$, and 0.399 for maximum \& minimum temperature and maximum relative humidity, respectively. While, the relation was negatively correlated and non- significant effect with minimum relative humidity $(r=-0.252, p=0.313)$. 
The multiple regression analysis indicated that the combined effect (E.V. \%) of these two factors together on the population density of thrips on onion plants during two successive seasons were 44.62 and 47.73, respectively. This means that two factors had strong effect on the activity of thrips, especially in the second season. Therefore, it could be stated that the combined effects of temperature and relative humidity as well as there are unconsidered factors other than temperature and relative humidity effect on the building up of thrips population such as onion plant age where the E.V\% for that factor on the population density of thrips on onion plant were 88.54 and $80.27 \%$ during both seasons, respectively.

Table 2. Effect of certain weather factors and plant age stages on the population of $T$. tabaci during the two seasons.

\begin{tabular}{|c|c|c|c|c|c|c|c|c|}
\hline \multirow[t]{2}{*}{ Seasons } & \multirow[t]{2}{*}{ factors } & \multicolumn{2}{|c|}{$\begin{array}{l}\text { Correlation } \\
\text { coefficient. }\end{array}$} & \multicolumn{5}{|c|}{ Multiple regression } \\
\hline & & $r$ & $\mathrm{p}$ & $b$ & $\mathrm{p}$ & $f$ & $\mathrm{p}$ & EV \% \\
\hline \multirow{8}{*}{$2015 / 2016$} & Temp. Max. & 0.467 & 0.051 & 1.368 & 0.395 & \multirow{4}{*}{2.62} & \multirow{4}{*}{0.0837} & \multirow{4}{*}{44.62} \\
\hline & Temp. Mini. & 0.509 & 0.031 & 0.317 & 0.901 & & & \\
\hline & R. H Max.. & 0.457 & 0.057 & 0.225 & 0.667 & & & \\
\hline & R.H. Mini. & -0.123 & 0.627 & -0.155 & 0.863 & & & \\
\hline & Age 1 & 0.567 & 0.014 & -9.240 & 0.106 & \multirow{3}{*}{36.06} & \multirow{3}{*}{0.0001} & \multirow{3}{*}{88.54} \\
\hline & Age 2 & 0.413 & 0.089 & 1.954 & 0.006 & & & \\
\hline & Age 3 & 0.272 & 0.275 & -0.085 & 0.001 & & & \\
\hline & $\begin{array}{l}\text { All weather } \\
\text { factors and } \\
\text { plant age } \\
\text { stages }\end{array}$ & - & - & - & - & 16.92 & 0.0001 & 92.21 \\
\hline \multirow{8}{*}{$2016 / 2017$} & Temp. Max. & 0.285 & 0.251 & -3.956 & 0.190 & \multirow{7}{*}{2.97} & \multirow{7}{*}{0.0605} & \multirow{7}{*}{47.73} \\
\hline & Temp. Mini. & 0.376 & 0.124 & 1.886 & 0.687 & & & \\
\hline & R. H Max.. & 0.212 & 0.399 & 0.595 & 0.403 & & & \\
\hline & R.H. Mini. & -0.252 & 0.313 & -1.346 & 0.323 & & & \\
\hline & Age 1 & 0.446 & 0.063 & -7.974 & 0.212 & & & \\
\hline & Age 2 & 0.287 & 0.248 & 1.862 & 0.028 & & & \\
\hline & Age 3 & 0.148 & 0.559 & -0.079 & 0.009 & & & \\
\hline & $\begin{array}{l}\text { All weather } \\
\text { factors and } \\
\text { plant age } \\
\text { stages }\end{array}$ & - & - & - & - & 7.68 & 0.0024 & 84.31 \\
\hline
\end{tabular}

The combined effect of the weather factors and onion plant ages on thrips population in the first season was $92.21 \%$ with highly significant and the other effects are due to another factors $(P=0.0001)$. Beside that the combined effect of the second season was lower than that recorded in the first season $(E V=84.31 \%)$ with highly significant relationship also $(P=0.0024)$. 
Finally, from the obtained results it could be concluded that weather factors as maximum \& minimum temperature and relative humidity did not give significant correlation with onion thrips population except minimum temperature had significant correlated in the first season. On the other hand, onion plant age as third polynomial relation $\left(y=a+b 1 x+b 2 x^{2}+b 3 x^{3}\right)$ resulted in strong and significant correlation and regression where EV values were 88.54 and $80.27 \%$ during tow successive seasons, respectively.

The abovementioned results of the effect of weather factors on the population density of thrips are partially agree with Hussien et al. (2010) they indicated that the population density of thrips nymph and adults were negatively correlated with maximum and minimum temperature while, the mean of R.H. affected positively. The combined effects together were 68.55 and $78.97 \%$ in the two seasons, respectively. Faraman et al. (2010) stated that abiotic factors are not responsible for population fluctuation of the thrips. There is a need to look into a combination of abiotic and biotic factors for developing better models. Amongst the biotic factors, natural enemies, physiological stages of the insect, concentration of hormone are equally important may be significant factors. Specially, the morphological and nutritional changes that occur in the onion leaves during the course of its development may be the determining factors for thrips population development. Observation are compatible with those of Domiciano et al. (1993) who observed that typical condition which favored rapid increase in the thrips population were temperature $\left(20.29^{\circ} \mathrm{C}\right)$ an the absence of rainfall.

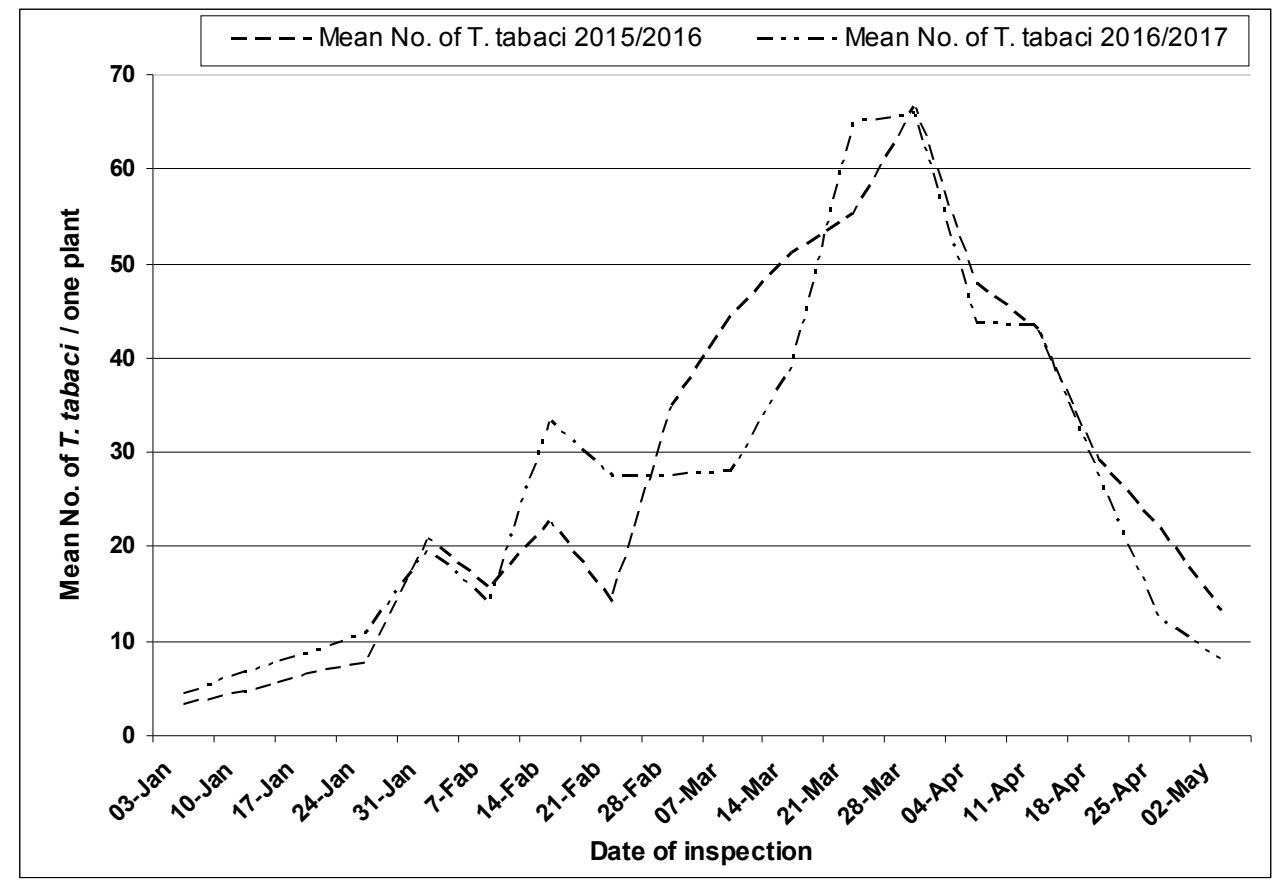

Fig. 1. Population density of T. tabaci Lind. on onion plantations during the two seasons. 


\section{REFERENCES}

1. Afifi, F.M.L. and M.F. Hayder. 1990. Effect of different intercropping systems on onion and garlic infestation with the cotton and onion thrips, Thrips tabaci lind. Bulletin of Faculity of Agriculture. University of Cairo, 41:3, 639-648.

2. Domiciano, N.L., A.Y. Ota and C.R. Jedardi. 1993. Population fluctuation of onion thrips on onion. Anaisada- sociedade. Ent. Brazil, 22: 77-83.

3. Elkhayat, E.F., F.F. Shalaby, F.M. Lotfy and A.R. Ibrahim. 1997. Thrips infestation to onion plants in relation to onion variety, planting date and nitrogen fertilization. Annals of Agricultural Science, Moshtohor, 35 (3): 1761-1777.

4. Farman Ullah, Maraj-ul-Mulk, Abid Farid, Muhammad Qasid Saeed and Shahid Sattar. 2010. Population Dynamics and Chemical Control of Onion Thrips (Thrips tabaci, Lind.). Pakistan J. Zool., vol. 42(4), pp. 401-406.

5. Hudak, K. and B. Penzes. 2004. Factors influencing on the population of the onion thrips on onion. Acta. Phytopathologica et Entomologica Hungarica, 39(1/3): 193-197.

6. Hussein, S.H.A., A.R.I. Hanafy and M.A.M. Tantawy. 2010. Effect of cultivars, some climatic factors and plant development stages on the population density of onion thrips, Thrips tabaci Lind. on garlic plant in Egypt. Fayoum J. Agric. Res. and Development 24:30-36.

7. Moawad, S.S. 2003. Effect of inter cropping potato crop with some medicinal and ornamental Plants on insect infestations. Bulletin of the National Research Center, Cairo; 28(3):337-346.

8. SAS Institute, 2008. SAS /STAT user's guide, version 9.2. SAS Institute, Cary, NC/ USA.

9. Waiganjo, M.M.1., L.M. Gitonga and J.M. Mueke. 2008; Effects of weather on thrips population dynamics and its implication on the thrips pest management. Afr. J. Hort. Sci. (1) 82:90. 


\section{تأثير بعض العوامل الجوية على تعداد حشرة تربس البصل على محصول البصل}

\section{ابراهيم عبدالحميد الصباغ}

$$
\text { معهُ بحوث وقاية النباتات - مركز البحوث الزراعية - الدقى - الجيزة - مصر }
$$

تم دراسة تاثير درجة الحرارة والرطوبة وكذلك مراحل نمو النبات على تعداد حشرة تربس

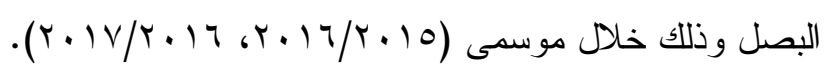

أظهرت الدراسة ان بداية ظهور اعداد التربس كان فى الاسبوع الاول من شهر يناير خلال

$$
\text { موسمى الدراسة وبدا التعداد فى الزيادة خله اثنهر فبر اير ومارس و ابريل . }
$$

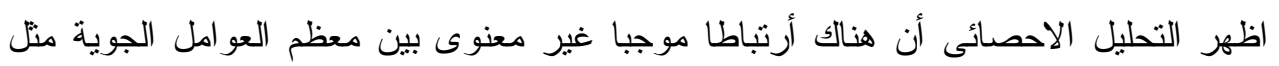
درجة الحر ارة العظمى و الصغرى ودرجة الرطوبة العظمى وبين تعداد التربس.

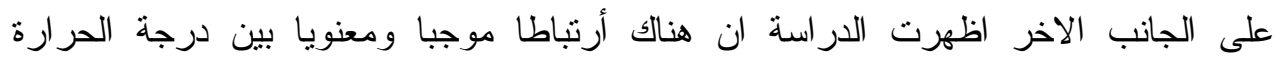
الصغرى و أعداد التربس فى حين ان هناك أرتباطا سالبا وغير معنوى بين درجة الرطوبة الصغري الصغي و اعداد الافة خلال الموسم الاول للار اسة.

من ناحية أخرى وخلال الموسم الثانى للار اسة أظهرت كل العوامل الجوية محل الدارلة الأسة ارتباطا موجبا غير معنوى مع أعداد التربس باستثناء درجة الرطوبة الصغرى اللذى أظهر ارتباطا سلبيا وغير معنويا. كما أظهرت الدراسة ان هناك علاقة ارتباط قوية بين تعداد حشرة التربس وبين عمر نبات 